\title{
Investigation of the microstructure, mechanical properties and cell viability of zirconia-toughened alumina composites reinforced with carbon nanotubes
}

\author{
Ipek AKIN ${ }^{\dagger}$ \\ Istanbul Technical University, Department of Metallurgical and Materials Engineering, \\ 34469 Maslak Istanbul, Turkey
}

\begin{abstract}
The addition of multi-wall carbon nanotubes (MWCNTs) to ceramic matrices can be utilized for special applications such as implant materials. In this study, zirconia toughened alumina (ZTA) composites having 10, 20 and 30 vol \% yttria stabilized zirconia (YSZ) with additions of $0.5,1$, and $2 \mathrm{wt} \%$ MWCNTs were prepared by spark plasma sintering (SPS) at $1400^{\circ} \mathrm{C}$ under $40 \mathrm{MPa}$ for $5 \mathrm{~min}$. Systematic investigation of the effects of CNT reinforcement on densification behavior, microstructure, mechanical properties (Vickers microhardness, indentation fracture toughness, and flexural strength) and biocompatibility (cell viability) of ZTA composites was performed. The results indicated that the mechanical properties of CNT reinforced aluminabased composites are strongly dependent on the amount and position of nanotubes in the microstructure and the strength of the cohesion of matrix grains and the nanotubes. Composites with 30 vol \% YSZ and $0.5 \mathrm{wt} \%$ CNTs exhibited the highest Vickers hardness, fracture toughness and flexure strength with values of $\sim 18 \mathrm{GPa}, 5.5 \mathrm{MPa} \cdot \mathrm{m}^{1 / 2}$ and $590 \mathrm{MPa}$, respectively. In addition, preliminary biocompatibility tests indicated that the composites showed no cytotoxicity to human osteoblast cells.
\end{abstract}

(C2015 The Ceramic Society of Japan. All rights reserved.

Key-words : Spark plasma sintering, Densification, Mechanical properties, Alumina, Carbon nanotube

[Received December 1, 2014; Accepted February 21, 2015]

\section{Introduction}

Over the last two decades, carbon nanotubes (CNTs) have attracted increasing scientific attention. This is due to their remarkable properties originating from their unique one-dimensional character. A combination of outstanding mechanical (elastic modulus $\sim 1.28 \mathrm{TPa}$, tensile strength $\sim 30 \mathrm{GPa}$ ), ${ }^{1), 2)}$ thermal (conductivity $>2000 \mathrm{~W} / \mathrm{mK}$ ) and electrical (conductivity $\left.>1.5 \times 10^{4} \mathrm{~S} / \mathrm{m}\right)^{3)}$ properties makes CNTs suitable reinforcing materials for different systems. The very high aspect ratio of CNTs enhances load transfer with the matrix and provides effective reinforcement. ${ }^{4)}$ Over the last fifteen years, different composite materials have been prepared by incorporation of single, double or multi-wall carbon nanotubes as toughening agents into a metal, ${ }^{5,, 6)}$ ceramic, mostly $\mathrm{Al}_{2} \mathrm{O}_{3}{ }^{7)-10)}$ or polymer matrices. ${ }^{11)}$ CNT-reinforced systems can be used for a broad spectrum of applications including aerospace vehicles, military applications, and electrical industry. In addition, CNTs have high potential for use in biological applications (such as biosensors and drug delivery) due to their high surface area, excellent chemical stability, and acceptable biocompatibility. ${ }^{12), 13)}$ CNTs have also been utilized for gene therapy, immunotherapy, and tissue regeneration. ${ }^{13)}$ In addition, CNTs can enhance bone growth and apatite formation. Zanello et al. reported that CNTs preserve bone formation and growth of bone-forming cells. ${ }^{14)}$ Webster et al. investigated the effect of carbon nano-fibers on osteoblast cells in an in vitro study, and they found that carbon nano-fibers enhance osteoblast activity and osseointegration. ${ }^{12)}$

The mechanical properties of multi and/or single wall carbon nanotube (SWCNT) reinforced ceramic matrix composites have

\footnotetext{
Corresponding author: I. Akin; E-mail: akinipe@itu.edu.tr
}

been investigated in different studies. However, the exact role of CNTs is unclear. For instance, Zhan et al. measured a fracture toughness of $\sim 9.7 \mathrm{MPa} \cdot \mathrm{m}^{1 / 2}$ for spark plasma sintered $\mathrm{Al}_{2} \mathrm{O}_{3}$ ceramics with 10 vol $\%$ SWCNTs. On the other hand, Wang et al. reported the fracture toughness as $\sim 3.3 \mathrm{MPa} \cdot \mathrm{m}^{1 / 2}$ for the same system. ${ }^{15)}$ Moreover, researchers found that CNT addition can prevent densification, and it can lead to weak or strong cohesion with the matrix grains depending on the CNT content. In this study, it was aimed to investigate and highlight the importance of nanotube position within the microstructure and the resulting effects on the properties of alumina-based ceramics. In addition, to the best of author's knowledge, the effects of CNT and carbon black (CB) addition on cell (human osteoblast) viability of zirconia toughened alumina ceramics has not been investigated so far.

High density alumina ceramics are widely used as femoral heads in total hip replacements (as an alternative to metallic materials), knee replacement prostheses, and dental implants. This is due to their high hardness $(\sim 23 \mathrm{GPa})$, high Young's modulus ( $\sim 400 \mathrm{GPa})$, biocompatibility, high wear and chemical resistance, and moderate flexure strength ( $\sim 595 \mathrm{MPa}){ }^{16)-18)}$ However, failure of the alumina components (with time in service) can originate from the slow crack growth characteristic of alumina. ${ }^{19), 20)}$ The incorporation of zirconia into alumina ceramics results in zirconia-toughened alumina (ZTA) ceramics. These have improved fracture toughness and strength values due to a stress induced tetragonal to monoclinic transformation. ${ }^{21)}$

The objective of this study was to investigate the influence of multi-wall CNT addition on the properties of zirconia-toughened alumina (ZTA) composites prepared by spark plasma sintering. The densification behavior, mechanical properties and preliminary cell viability studies of $\mathrm{Al}_{2} \mathrm{O}_{3}$ based composites were studied. 


\section{Experimental procedure}

\subsection{Composite preparation}

High purity $\alpha-\mathrm{Al}_{2} \mathrm{O}_{3}$ (Baikalox SM8, Baikowski, USA, primary particle size $50 \mathrm{~nm}$, purity $>99.99 \%$, surface area $\sim 10$ $\mathrm{m}^{2} / \mathrm{g}$ ), yttria stabilized zirconia ( $\mathrm{YSZ}, \mathrm{ZrO}_{2}+3 \mathrm{~mol} \% \mathrm{Y}_{2} \mathrm{O}_{3}$, Tosoh, Japan, primary particle size $50 \mathrm{~nm}$, purity $>99.99 \%$, surface area $\sim 16 \mathrm{~m}^{2} / \mathrm{g}$ ) and multi-wall carbon nanotubes (MWCNTs, Carbon NT\&F21, MT-MW-010-02, 10-20 nm in diameter, 1-2 $\mu \mathrm{m}$ in length) were used as starting materials (Table 1).

The raw materials were weighed in appropriate quantities, and homogeneous mixtures of $\mathrm{Al}_{2} \mathrm{O}_{3}$ and $\mathrm{YSZ}$ were ball milled in ethanol for $24 \mathrm{~h}$ and then dried. Micrographs of the starting powders of $\mathrm{Al}_{2} \mathrm{O}_{3}$ and $\mathrm{YSZ}$, and a powder mixture of ball milled $70 \mathrm{~A} 30 \mathrm{Z}$ are shown in Fig. S1 in the Supplementary material. The MWCNTs $(0.5,1$ and $2 \mathrm{wt} \%)$ were dispersed in $250 \mathrm{ml}$ ethanol, using an ultrasonic homogenizer (Bandelin Sonopuls HD 2200, operating at $50 \%$ amplitude with on and off cycles) for $45 \mathrm{~min}$. Then, the dispersed MWCNTs were mixed with $\mathrm{Al}_{2} \mathrm{O}_{3}-\mathrm{YSZ}$ powder mixture slurry and dispersed again with a more powerful ultrasonic agitation (Hielscher UP400S, operating at 50\% amplitude with on and off cycles) for $1 \mathrm{~h} . \mathrm{Al}_{2} \mathrm{O}_{3}$, YSZ and MWCNTs (in ethanol media) were stirred until most of the ethanol evaporated, and then the powder mixture was dried at $105^{\circ} \mathrm{C}$ for $24 \mathrm{~h}$ in a drying oven. The resulting soft and unagglomerated powder mixture was ground in an agate mortar.

To compare the effects of carbon type, the same amounts ( $2 \mathrm{wt} \%$ ) of carbon black (CB) and carbon nanotubes were used as reinforcement additives for the sample 70A30Z.

\subsection{Sintering of composites}

The sintering experiments were carried out using a spark plasma sintering (SPS) apparatus (SPS 7.40 MK-VII, SPS Syntex Inc.). A hollow cylinder graphite die with a $95 \mathrm{~mm}$ outer diameter, a $50 \mathrm{~mm}$ inner diameter and a $50 \mathrm{~mm}$ height was filled with the powder mixture. A graphitic sheet was placed between the punches and the powder, and between the die and the powder for easy removal and better conductivity. In addition, carbon felt was used to minimize radiation losses.

An optical pyrometer (Chino, IR-AH), capable of operating above $570^{\circ} \mathrm{C}$, was focused on a small hole in the graphite die. This was used to monitor and control the temperature. The SPS process can be performed automatically (temperature-controlled mode) or manually (current-controlled mode). In this study, the composites were sintered using a current-controlled mode by monitoring the shrinkage of the specimens during the sintering. The target was to achieve nearly full densification of the $\mathrm{Al}_{2} \mathrm{O}_{3}$ based composites with minimal grain growth. A uniaxial pressure of $40 \mathrm{MPa}$ and a pulsed direct current (12 ms/on, $2 \mathrm{~ms} /$ off ) were applied during the entire SPS process. The uniaxial pressure was released during cooling for all of the samples. Pure alumina was sintered at $1350^{\circ} \mathrm{C}$. The $\mathrm{Al}_{2} \mathrm{O}_{3}-\mathrm{YSZ}$ and $\mathrm{Al}_{2} \mathrm{O}_{3}-\mathrm{YSZ}-\mathrm{CNT}$ composites were sintered at $1400^{\circ} \mathrm{C}$ for $300 \mathrm{~s}$ with a heating rate of $3^{\circ} \mathrm{C} / \mathrm{s}$ in a vacuum.

Linear shrinkage of the specimens was continuously monitored during the SPS process based on displacement of the punch rods. A blank run was used (with the sintering conditions) to determine the effects of thermal expansion of the graphite die and punches. The sintered specimens were in the form of pellets with $50 \mathrm{~mm}$ diameter and approximately $4 \mathrm{~mm}$ thickness. The specimens were characterized after sandblasting. To remove carbon contamination, the samples were heat treated at $950^{\circ} \mathrm{C}$ for $20 \mathrm{~min}$ in an open atmosphere. The duration of the heat treatment was kept as short as possible to avoid grain growth.

\subsection{Characterization of composites}

The densities of the sintered samples were measured by the Archimedes method in distilled water. The resulting values were converted to relative densities. The theoretical density depends on the composition. This is calculated using the densities and the volume and/or mass fractions of the $\mathrm{Al}_{2} \mathrm{O}_{3}\left(3.97 \mathrm{~g} / \mathrm{cm}^{3}\right)$, YSZ $\left(6.05 \mathrm{~g} / \mathrm{cm}^{3}\right)$ and CNT $\left(1.9 \mathrm{~g} / \mathrm{cm}^{3}\right)$. The crystalline phases were identified by X-ray diffractometry (XRD; MiniFlex, Rigaku Corp.) in the $2 \theta$ range of $20-80^{\circ}$ with $\mathrm{Cu} \mathrm{K} \alpha$ radiation. The microstructures of the sintered samples were investigated using scanning electron microscopy (FESEM; JSM 7000F, JEOL Ltd.). SEM analyses were performed on fracture surfaces of $\mathrm{Al}_{2} \mathrm{O}_{3}-\mathrm{YSZ}$ and $\mathrm{Al}_{2} \mathrm{O}_{3}-\mathrm{YSZ}-\mathrm{CNT}$ composites. The linear intercept method (by using MagniSci and Image $\mathrm{J}$ software) was utilized for average grain size measurement for thermally etched, polished surfaces of $\mathrm{Al}_{2} \mathrm{O}_{3}-\mathrm{YSZ}$ composites. All results are presented in Table S1 in Supplementary material. A micro-Raman spectroscope (LabRam 800, Horiba Scientific, Jobin Yvon, France) was utilized to determine whether the carbon nanotubes were preserved after the SPS process. Vickers hardness was measured under a load of $9.8 \mathrm{~N}$. Fracture toughness was evaluated by a microhardness tester (VHMOT, Leica Corp.) under a load of $19.6 \mathrm{~N}$. The fracture toughness was determined from the half-

Table 1. Composition, relative density, hardness, fracture toughness and flexural strength values of spark plasma sintered specimens

\begin{tabular}{|c|c|c|c|c|c|c|c|c|c|}
\hline Composition & Code & $\begin{array}{c}\mathrm{Al}_{2} \mathrm{O}_{3} \\
\text { (vol \%) }\end{array}$ & $\begin{array}{c}\text { YSZ } \\
\text { (vol\%) }\end{array}$ & $\begin{array}{c}\text { CNT } \\
(\mathrm{wt} \%)\end{array}$ & $\begin{array}{c}\mathrm{CB} \\
(\mathrm{wt} \%)\end{array}$ & $\begin{array}{c}\text { Relative } \\
\text { Density } \\
(\%)\end{array}$ & $\begin{array}{l}\text { Hardness } \\
(\mathrm{GPa})\end{array}$ & $\begin{array}{c}\text { Fracture } \\
\text { toughness } \\
\left(\mathrm{MPa} \cdot \mathrm{m}^{1 / 2}\right)\end{array}$ & $\begin{array}{c}\text { Flexural } \\
\text { strength } \\
(\mathrm{MPa})\end{array}$ \\
\hline $100 \mathrm{Al}_{2} \mathrm{O}_{3}$ & $100 \mathrm{~A}$ & 100 & - & - & - & 99.7 & $19.38 \pm 0.32$ & $2.82 \pm 0.09$ & $302 \pm 47$ \\
\hline $90 \mathrm{Al}_{2} \mathrm{O}_{3}-10 \mathrm{YSZ}$ & $90 \mathrm{~A} 10 \mathrm{Z}$ & 90 & 10 & - & - & 99.5 & $20.56 \pm 0.25$ & $4.80 \pm 0.03$ & $400 \pm 15$ \\
\hline $90 \mathrm{Al}_{2} \mathrm{O}_{3}-10 \mathrm{YSZ}-0.5 \mathrm{CNT}$ & $90 \mathrm{~A} 10 \mathrm{Z}-0.5 \mathrm{CNT}$ & 90 & 10 & 0.5 & - & 99.3 & $19.61 \pm 0.36$ & $4.92 \pm 0.02$ & $453 \pm 54$ \\
\hline $90 \mathrm{Al}_{2} \mathrm{O}_{3}-10 \mathrm{YSZ}-1.0 \mathrm{CNT}$ & 90A10Z-1CNT & 90 & 10 & 1.0 & - & 98.7 & $18.53 \pm 0.28$ & $4.73 \pm 0.03$ & $404 \pm 61$ \\
\hline $90 \mathrm{Al}_{2} \mathrm{O}_{3}-10 \mathrm{YSZ}-2.0 \mathrm{CNT}$ & 90A10Z-2CNT & 90 & 10 & 2.0 & - & 98.3 & $17.03 \pm 0.16$ & $4.31 \pm 0.08$ & $356 \pm 79$ \\
\hline $80 \mathrm{Al}_{2} \mathrm{O}_{3}-20 \mathrm{YSZ}$ & $80 \mathrm{~A} 20 \mathrm{Z}$ & 80 & 20 & - & - & 99.6 & $19.15 \pm 0.26$ & $5.12 \pm 0.03$ & $558 \pm 46$ \\
\hline $80 \mathrm{Al}_{2} \mathrm{O}_{3}-20 \mathrm{YSZ}-0.5 \mathrm{CNT}$ & 80A20Z-0.5CNT & 80 & 20 & 0.5 & - & 99.1 & $18.65 \pm 0.10$ & $5.26 \pm 0.02$ & $574 \pm 58$ \\
\hline $80 \mathrm{Al}_{2} \mathrm{O}_{3}-20 \mathrm{YSZ}-1.0 \mathrm{CNT}$ & 80A20Z-1CNT & 80 & 20 & 1.0 & - & 99.1 & $17.90 \pm 0.44$ & $4.92 \pm 0.03$ & $469 \pm 89$ \\
\hline $80 \mathrm{Al}_{2} \mathrm{O}_{3}-20 \mathrm{YSZ}-2.0 \mathrm{CNT}$ & 80A20Z-2CNT & 80 & 20 & 2.0 & - & 98.0 & $16.81 \pm 0.26$ & $4.54 \pm 0.03$ & $358 \pm 46$ \\
\hline $70 \mathrm{Al}_{2} \mathrm{O}_{3}-30 \mathrm{YSZ}$ & $70 \mathrm{~A} 30 \mathrm{Z}$ & 70 & 30 & - & - & 99.6 & $18.60 \pm 0.40$ & $5.40 \pm 0.02$ & $589 \pm 64$ \\
\hline $70 \mathrm{Al}_{2} \mathrm{O}_{3}-30 \mathrm{YSZ}-0.5 \mathrm{CNT}$ & 70A30Z-0.5CNT & 70 & 30 & 0.5 & - & 98.9 & $17.82 \pm 0.20$ & $5.46 \pm 0.02$ & $591 \pm 98$ \\
\hline $70 \mathrm{Al}_{2} \mathrm{O}_{3}-30 \mathrm{YSZ}-1.0 \mathrm{CNT}$ & 70A30Z-1CNT & 70 & 30 & 1 & - & 98.6 & $17.45 \pm 0.34$ & $5.18 \pm 0.03$ & $490 \pm 87$ \\
\hline $70 \mathrm{Al}_{2} \mathrm{O}_{3}-30 \mathrm{YSZ}-2.0 \mathrm{CNT} *$ & 70A30Z-2CNT & 70 & 30 & 2 & - & 98.0 & $16.95 \pm 0.26$ & $4.62 \pm 0.03$ & $359 \pm 56$ \\
\hline $70 \mathrm{Al}_{2} \mathrm{O}_{3}-30 \mathrm{YSZ}-2.0 \mathrm{CB}^{* *}$ & $70 \mathrm{~A} 30 \mathrm{Z}-2 \mathrm{CB}$ & 70 & 30 & - & 2 & 98.0 & $16.15 \pm 0.32$ & $4.85 \pm 0.04$ & $432 \pm 32$ \\
\hline
\end{tabular}


length of a crack formed around the indentation by using the following equation.

$$
\mathrm{K}_{\mathrm{IC}}=0.016\left(\mathrm{E}_{\mathrm{c}} / \mathrm{H}\right)^{1 / 2}\left(\mathrm{P} / \mathrm{c}^{3 / 2}\right)
$$

Equation (1) was derived from Anstis et al, ${ }^{22)}$ based on the results of Lawn et al. ${ }^{22)}$ In this equation, $\mathrm{E}_{\mathrm{c}}$ is Young's modulus (GPa) of the composites and is measured using a four-point bending test, $\mathrm{H}$ is the Vickers micro-hardness (GPa), $\mathrm{P}$ is the load $(\mathrm{N})$, and $\mathrm{c}$ is half of the average crack length resulting from the indentation. The average value (from 20 measurements) for each sample was used to evaluate the hardness and fracture toughness. The flexural strength of the materials was determined by fourpoint bending in accordance with ASTM Standard C1161-02a (Standard Test Method for Flexural Strength of Advanced Ceramics at Ambient Temperature) for type-B rectangular cross section bars (width: $4 \mathrm{~mm}$, depth: $3 \mathrm{~mm}$, length: $45 \mathrm{~mm}$ ). The longitudinal edges of the specimens were chamfered and then polished to eliminate burrs. Flexural strength measurements were carried out by a universal test machine (Instron Corp., 5581, USA, maximum load capacity is $50 \mathrm{kN}$ ). A center load was applied with a cross-head speed of $0.5 \mathrm{~mm} / \mathrm{min}$, and data were recorded up to failure. Six bars were fractured for each composition to determine the averages and standard deviations.

To assess the biocompatibility of the $\mathrm{Al}_{2} \mathrm{O}_{3}$ based composites, cell viability was evaluated by the cell proliferation and viability assay WST-1 \{4-[3-(4-iodophenyl)-2-(4-nitrophenyl)-2H-5tetrazolio]-1,3-benzene disulfonate, Roche Applied Science, Mannheim, Germany\} with the human osteoblast cell line hFOB 1.19 (ATCC number CRL-11372). The specimens were sterilized and placed into flat-bottom 24-well tissue culture plates. Cells were seeded on sterile blend films at a density of $1.0 \times 10^{5}$ cells per well in $1 \mathrm{~mL}$ Dulbecco's Modified Eagle's Medium (DMEM) (without phenol red) supplemented with $10 \%$ fetal bovine serum (FBS), penicillin (100 units $/ \mathrm{mL})$ and streptomycin $(100 \mu \mathrm{g} / \mathrm{mL})$. These were then incubated for $24 \mathrm{~h}$ in an atmosphere of $5 \% \mathrm{CO}_{2}$ at $33^{\circ} \mathrm{C}$. After incubation for $24 \mathrm{~h}$, WST-1 reagent $(100 \mu \mathrm{L})$ was added directly to the culture wells. After $2 \mathrm{~h}$ of incubation with WST- 1 at $37^{\circ} \mathrm{C}$, the WST-1 reaction products were transferred from 24-well plates to 96-well plates, and the absorbance was measured at $450 \mathrm{~nm}$ with a GloMax Multi + Microplate Multimode Reader (Promega, USA). For reference purposes, cells were seeded on the tissue-culture polystyrene plate with culture medium without the sample (designated as control) under the same seeding conditions. Control cells were considered 100\% viable. Statistical analyses were performed by one-way ANOVA followed by the Tukey test for multiple comparisons using the Prism analysis program (Graphpad, V 5.0).

\section{Results and discussion}

\subsection{Densification behavior and crystalline phases}

The densification of the specimens during the SPS process was evaluated by the displacement of punch rods due to the shrinkage of the samples. The densification behavior of $\mathrm{Al}_{2} \mathrm{O}_{3}$ and $\mathrm{Al}_{2} \mathrm{O}_{3}-$ YSZ binary composites have been reported in our previous studies. ${ }^{16), 23)}$ Briefly, the addition of 10 vol $\%$ YSZ increased the starting and completion temperatures of pure $\mathrm{Al}_{2} \mathrm{O}_{3}$ due to the higher melting temperature of YSZ. Further addition of YSZ resulted in the formation of fine grained microstructure and enhanced sintering by reducing the onset and final temperatures of shrinkage. In this study, Fig. 1(a) shows the displacement of $\mathrm{Al}_{2} \mathrm{O}_{3}-\mathrm{YSZ}$ composites containing $30 \mathrm{vol} \% \mathrm{YSZ}$ (70A30Z), 1 and $2 \mathrm{wt} \%$ carbon nanotube (70A30Z-1CNT and 70A30Z-2CNT) and $2 \mathrm{wt} \%$ carbon black $(70 \mathrm{~A} 30 \mathrm{Z}-2 \mathrm{CB})$ at $800-1400^{\circ} \mathrm{C}$, and
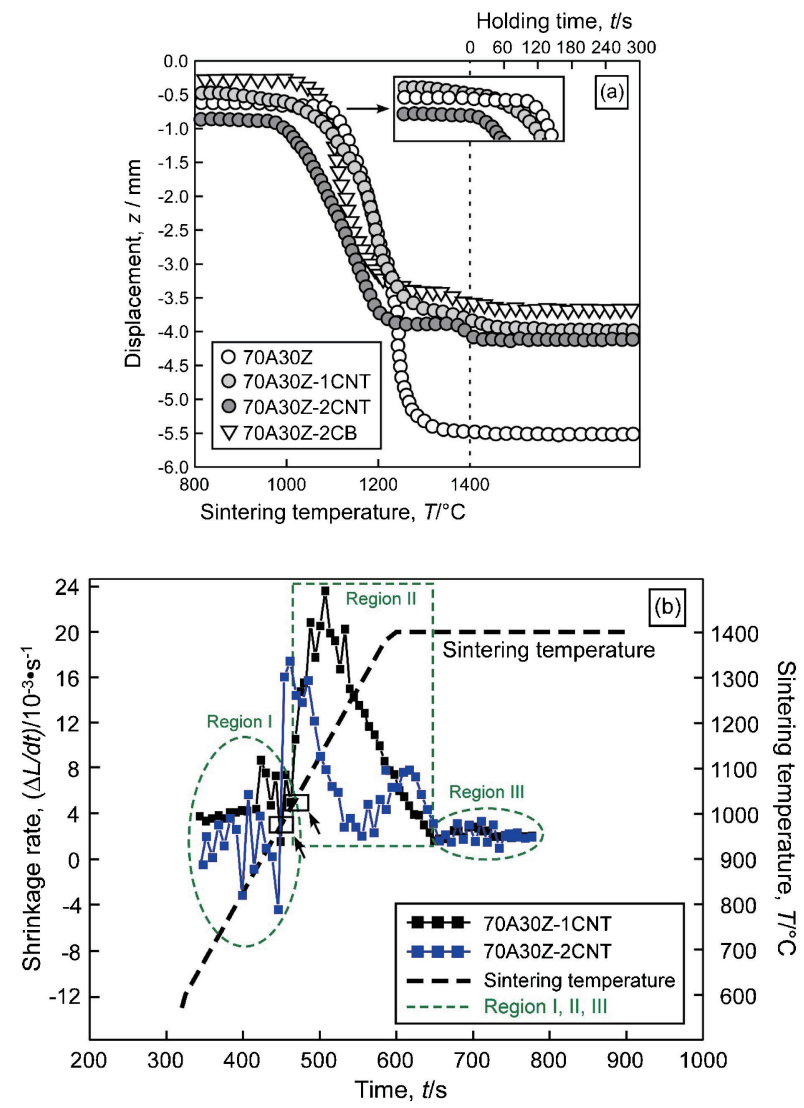

Fig. 1. Relationship between displacement and temperature, and time dependence of isothermal displacement of 70A30Z, 70A30Z-1CNT, $70 \mathrm{~A} 30 \mathrm{Z}-2 \mathrm{CNT}$ and $70 \mathrm{~A} 30 \mathrm{Z}-2 \mathrm{CB}$ ceramics at $800-1400^{\circ} \mathrm{C}$ (a), and shrinkage rate-sintering temperature-time curves for 70A30Z-1CNT and 70A30Z-2CNT ceramics, dashed line represents the sintering temperature (b).

isothermal shrinkage at $1400^{\circ} \mathrm{C}$ for $300 \mathrm{~s}$. In addition, Fig. 1(b) shows the shrinkage rate $\left[\mathrm{d}\left(\Delta \mathrm{L} / \mathrm{L}_{0}\right) / \mathrm{dt}\right]$ of $70 \mathrm{~A} 30 \mathrm{Z}-1 \mathrm{CNT}$ and 70A30Z-2CNT composites. $\mathrm{L}_{0}$ represents the thickness of green powder compact with applied pressure before sintering. Shrinkage rate values were plotted as a function of sintering time and temperature. The additions of $1 \mathrm{wt} \% \mathrm{CNT}$ and $2 \mathrm{wt} \% \mathrm{CB}$ exhibited similar behavior on densification of $70 \mathrm{~A} 30 \mathrm{Z}$ and decreased the onset temperature of shrinkage from 1090 to 1040 and $1035^{\circ} \mathrm{C}$, respectively, but increased the shrinkage completion temperature from 1330 to $1400^{\circ} \mathrm{C}$. Further reduction in the starting temperature of shrinkage $\left(985^{\circ} \mathrm{C}\right)$ was observed with the addition of $2 \mathrm{wt} \%$ of CNTs. Similar to the case for $1 \mathrm{wt} \%$ CNTs, shrinkage completed at $1400^{\circ} \mathrm{C}$. The shrinkage rate curves given in Fig. 1(b) had three regions, i.e., sharp and moderate peaks at lower temperatures $\sim 570-900^{\circ} \mathrm{C}$ (Region I), broad peaks with the maximum shrinkage rates (Region II), and small peaks during the initial stage of the holding time (Region III). The addition of different amounts of CNTs resulted in different peak formations. The shrinkage rate curve of 70A30Z-1CNT showed only one main peak (with a maximum value at $1155^{\circ} \mathrm{C}$ ), and displacement rate started to increase at $\sim 1040^{\circ} \mathrm{C}$, which is attributed to the initiation of densification [indicated by an arrow in Fig. 1(b)]. The shrinkage rate curve for the $70 \mathrm{~A} 30 \mathrm{Z}-2 \mathrm{CNT}$ had two broad peaks at temperatures of $\sim 900-1400^{\circ} \mathrm{C}$. The first and second peaks had maximum rates at 1020 and $1400^{\circ} \mathrm{C}$, respectively. Comparison of the two curves in Fig. 1(b) indicates that $1 \mathrm{wt} \%$ CNT addition resulted in higher shrinkage rates with one broad peak. The effects 
of CNTs on the densification behavior of ceramic matrix composites have been reported in previous studies. ${ }^{8), 24)-26)}$ The authors reported that CNTs can affect the densification process in manners that depend on the dispersion characteristics of the CNTs and the nature of the matrix material. The existence of carbon-based additives at grain boundaries in alumina-based ceramics can act as a barrier to prevent densification process. ${ }^{27)}$ The two-stage shrinkage behavior of the composite with $2 \mathrm{wt} \% \mathrm{CNTs}$ and the differences in densification results obtained from $70 \mathrm{~A} 30 \mathrm{Z}$ and $70 \mathrm{~A} 30 \mathrm{Z}$ with carbon additives might have been caused by those situations.

Table 1 shows the variations of the relative densities of the samples as a function of composition. A relative density of 99.7 was achieved for monolithic $\mathrm{Al}_{2} \mathrm{O}_{3}$ sintered at $1350^{\circ} \mathrm{C}$. Similarly, a relative density of more than $99.5 \%$ was obtained for $\mathrm{Al}_{2} \mathrm{O}_{3}-$ YSZ composites sintered at $1400^{\circ} \mathrm{C}$. However, negligible reductions in the relative densities were detected for $\mathrm{Al}_{2} \mathrm{O}_{3}-\mathrm{YSZ}-$ CNT composites depending on the CNT content. Reductions in densities of $0.2-0.7 \%$ were observed for $0.5 \%$ CNT addition. Furthermore, the reductions in relative densities became higher for $2 \mathrm{wt} \%$ CNT addition with an average reduction of $1.6 \%$. This could be associated with the presence of CNTs along grain boundaries. Such prevention of densification has been previously reported. ${ }^{26), 27)} \mathrm{A}$ study by Ahmad et al. ${ }^{26)}$ on hot pressed $\mathrm{Al}_{2} \mathrm{O}_{3}-$ CNT composites found that additions of 2 and $5 \mathrm{wt} \% \mathrm{CNTs}$ resulted in 0.5 and $3.4 \%$ reductions in density. Echeberria et al. ${ }^{27)}$ studied the spark plasma sintered SWCNTs and MWCNTs reinforced zirconia-toughened alumina composites and reported relative density reduction with increasing well-dispersed CNTs content. In addition, An et al. ${ }^{28)}$ reported that CNTs in alumina matrix decrease mass transportation during sintering and inhibit the densification process. Bakhsh et al. ${ }^{10)}$ demonstrated that
CNTs at the grain boundaries of alumina matrix cause a retardation to grain growth at sintering temperature.

X-ray diffraction analysis (Fig. S2 in Supplementary material) showed all of the composites to be binary phases. All of the samples were indexed to characteristic peaks of $\mathrm{Al}_{2} \mathrm{O}_{3}$ (JCPDS: 71-1683) and tetragonal $\mathrm{ZrO}_{2}$ (JCPDS: 50-1089), irrespective of the $\mathrm{YSZ}$ and CNT content.

\subsection{Microstructural observation}

Monolithic $\mathrm{Al}_{2} \mathrm{O}_{3}$ and $\mathrm{Al}_{2} \mathrm{O}_{3}-\mathrm{YSZ}$ composites (free of CNTs additions) were also sintered for comparison with $\mathrm{CNT}$ reinforced samples. Fracture surface micrographs of $\mathrm{Al}_{2} \mathrm{O}_{3}$ and binary composites are provided in Fig. 2. In addition, the micrographs of polished and thermally etched (at $1350^{\circ} \mathrm{C}$ for $\mathrm{Al}_{2} \mathrm{O}_{3}$ and $1400^{\circ} \mathrm{C}$ for $\mathrm{Al}_{2} \mathrm{O}_{3}-\mathrm{YSZ}$ composites for $10 \mathrm{~min}$ ) surfaces of $\mathrm{Al}_{2} \mathrm{O}_{3}$ and $\mathrm{Al}_{2} \mathrm{O}_{3}-\mathrm{YSZ}$ composites are shown in Figs. S3(a)-S3(d) in the Supplementary material. The microstructural observations of the samples are in agreement with the measured relative densities. Monolithic $\mathrm{Al}_{2} \mathrm{O}_{3}$ [Fig. 2(a)] contained both large and small equiaxed grains $(0.5-3 \mu \mathrm{m}$ in size) with an average grain size of $\sim 2.11 \mu \mathrm{m}$ and straight grain boundaries. The fracture surface of pure alumina is inter-granular in nature. Figure 2(b) shows the fracture surface of $90 \mathrm{~A} 10 \mathrm{Z}$ composite, where the alumina (gray) and YSZ grains (white) have average grain sizes of $\sim 1.90$ and $\sim 0.88 \mu \mathrm{m}$, respectively. Grain growth of the alumina was inhibited with the addition of $10 \mathrm{vol} \%$ YSZ. The presence of YSZ particles as a secondary phase could be beneficial with respect to the inhibition of grain growth. Fine zirconia particles can have a pinning effect on the grain boundaries of alumina [Fig. S3(e)]. This impedes grain boundary migration. ${ }^{16), 29), 30)}$ Larger volume fractions of second phase particles are more effective in pinning the boundaries. Therefore, there is a clear decrease in the sizes of
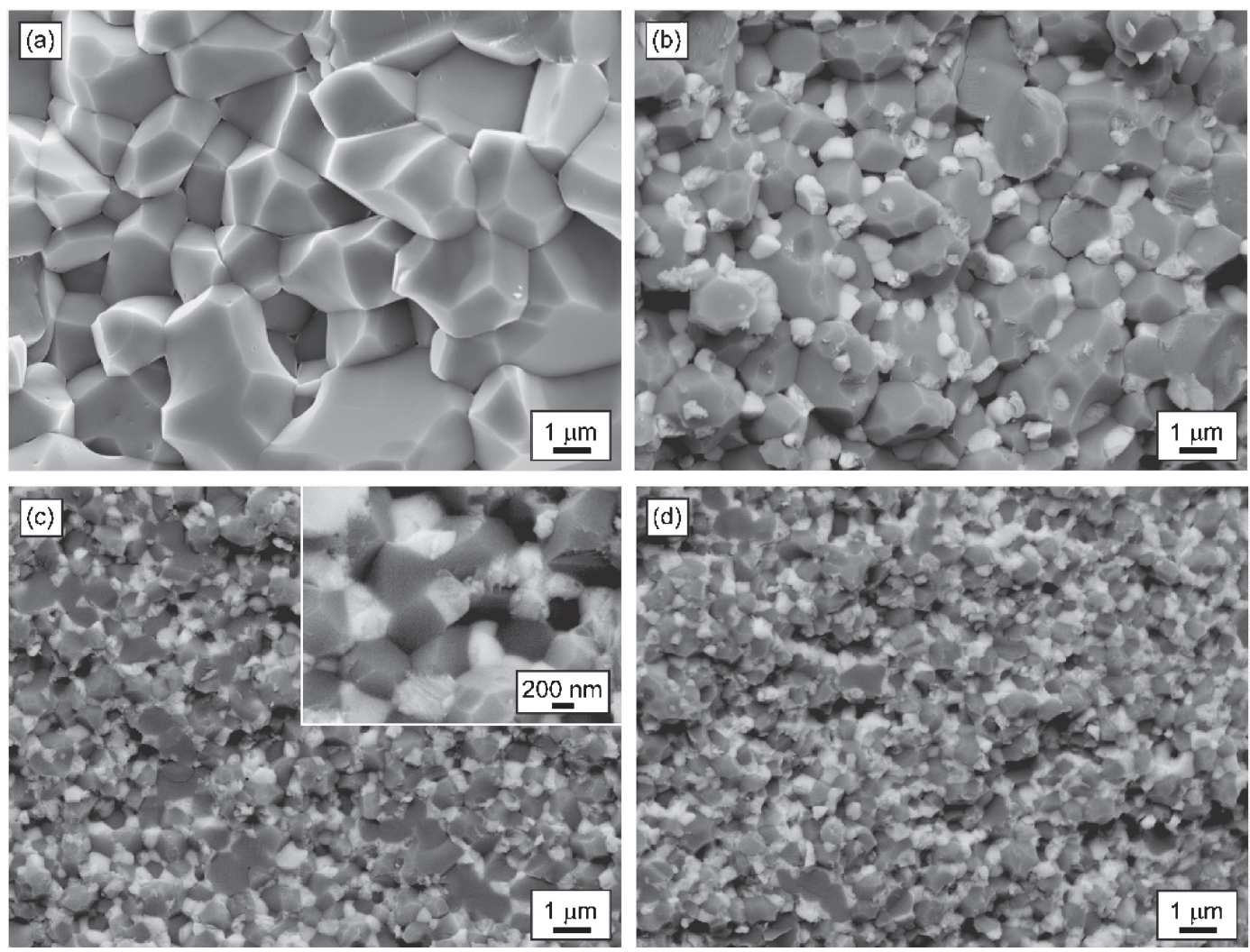

Fig. 2. SEM images of fracture surfaces of $100 \mathrm{~A}(\mathrm{a}), 90 \mathrm{~A} 10 \mathrm{Z}(\mathrm{b}), 80 \mathrm{~A} 20 \mathrm{Z}$ (c), and $70 \mathrm{~A} 30 \mathrm{Z}$ (d) ceramics sintered at $1400^{\circ} \mathrm{C}$ for $300 \mathrm{~s}$. 

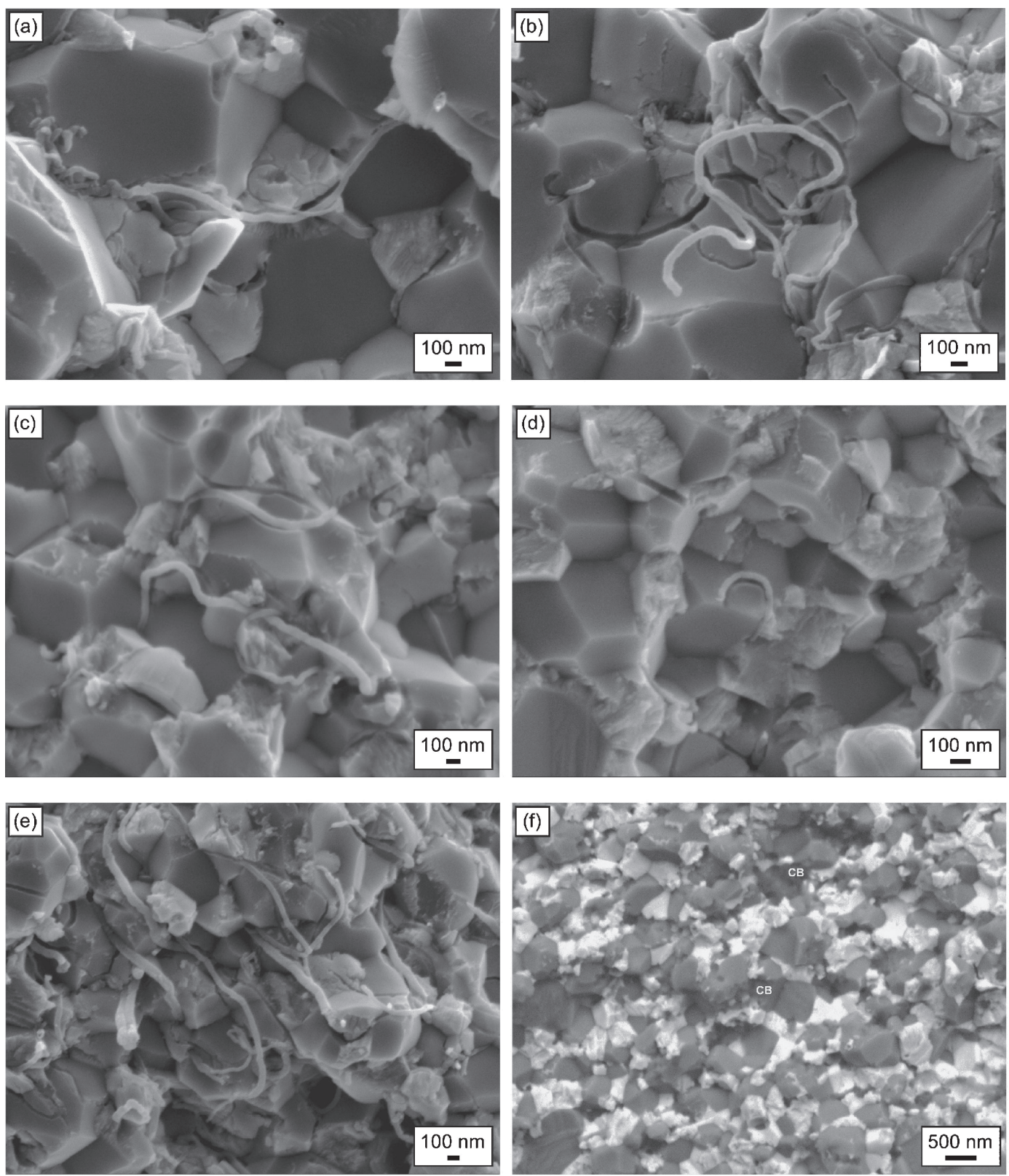

Fig. 3. SEM images of fracture surfaces of 90A10Z-0.5CNT (a), 90A10Z-1CNT (b), 80A20Z-0.5CNT (c), 70A30Z-0.5CNT (d), $70 \mathrm{~A} 30 \mathrm{Z}-2 \mathrm{CNT}(\mathrm{e})$, and $70 \mathrm{~A} 30 \mathrm{Z}-2 \mathrm{CB}$ (f) ceramics sintered at $1400^{\circ} \mathrm{C}$ for $300 \mathrm{~s}$.

the $\mathrm{Al}_{2} \mathrm{O}_{3}$ grains as the YSZ content increases from 10 to 20 vol $\%$ and then to $30 \mathrm{vol} \%$ [Figs. 2(b)-2(d) and Figs. S3(a)$\mathrm{S} 3(\mathrm{~d})]$. Average grain sizes of $\mathrm{Al}_{2} \mathrm{O}_{3}$ and $\mathrm{YSZ}$ grains were measured as $\sim 1.44$ and $\sim 0.52 \mu \mathrm{m}$ for $80 \mathrm{~A} 20 \mathrm{Z}$, and $\sim 0.54$ and $\sim 0.23$ $\mu \mathrm{m}$ for $70 \mathrm{~A} 30 \mathrm{Z}$ composites, respectively. The fracture surfaces of carbon nanotube (CNT) and carbon black (CB) reinforced $\mathrm{Al}_{2} \mathrm{O}_{3}-\mathrm{YSZ}$ composites are shown in Figs. 3(a)-3(f), respectively. The micrographs of the $\mathrm{Al}_{2} \mathrm{O}_{3}-\mathrm{YSZ}-\mathrm{CNT}$ composites clearly show the individually dispersed CNTs within the matrix [Figs. 3(a)-3(e)]. There was no evidence of the formation of entangled or bundled CNT clusters. CNTs were located mainly in inter-granular regions. This result is similar to those reported in other studies. ${ }^{15), 24), 31)}$ In addition, the wrapping of CNTs [Fig. 3(a)] and the bending of long CNTs [Fig. 3(b)] were observed. CNTs conformed to the shapes of the boundaries of the $\mathrm{Al}_{2} \mathrm{O}_{3}$ and $\mathrm{YSZ}$ grains [Figs. 3(a)-3(d)]. Consequently, the cohesion between matrix grains and CNTs appeared to be weakened due to the positioning of CNTs in inter-granular regions in the microstructure.

The presence of CNTs in the matrix did not change the fracture mode, i.e., inter-granular fracture was observed for both CNT free and CNT reinforced composites. However, the addition of CNTs reduced the sizes of the $\mathrm{Al}_{2} \mathrm{O}_{3}$ and $\mathrm{YSZ}$ grains. The grain size of $\mathrm{Al}_{2} \mathrm{O}_{3}$ decreased from $0.78-1$ to $0.5-0.75 \mu \mathrm{m}$ with the addition of $1 \mathrm{wt} \%$ of CNTs in the 80A20Z composite. The grain size reduction due to CNTs was more pronounced for YSZ grains. The presence of $1 \mathrm{wt} \%$ of CNTs along grain boundaries resulted in an approximately 50\% reduction in size of the YSZ grains. Similar results were reported by Ahmad et al. for hotpressed yttria-doped alumina composites having $2 \mathrm{wt} \% \mathrm{CNTs}^{32}$ ) The observed grain size refinement is most likely due to grain boundary pinning by CNTs, based on their tendency to be located at grain boundaries (as shown in fracture surface micrographs).

Figure 3(f) shows the effect of $2 \mathrm{wt} \%$ of carbon black (CB) on 


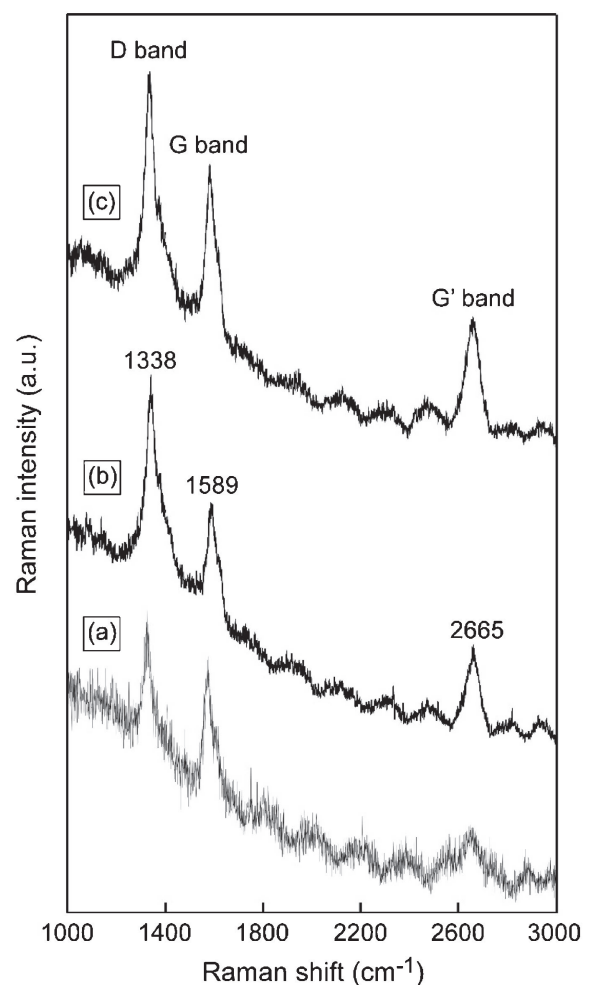

Fig. 4. Raman spectra of the pristine multiwall carbon nanotubes (a), 80A20Z-2CNT (b), and 70A30Z-2CNT ceramics (c).

the microstructure of the $70 \mathrm{~A} 30 \mathrm{Z}$ sample. This sample was also sintered at $1400^{\circ} \mathrm{C}$ for $300 \mathrm{~s}$. The microstructure of the $70 \mathrm{~A} 30 \mathrm{Z}$ composite with $2 \mathrm{wt} \%$ of CNTs was substantially different from that resulting from the addition of $2 \mathrm{wt} \% \mathrm{CB}$. Carbon black regions are labeled (as $\mathrm{CB}$ ) in Fig. 3(f). The presence of $\mathrm{CB}$ changed the mode of matrix fracture from inter-granular fracture to a mixture of inter-granular and trans-granular fracture. The addition of $2 \mathrm{wt} \% \mathrm{CB}$ slightly reduced the average grain size of the $\mathrm{Al}_{2} \mathrm{O}_{3}$ (from 0.85 to $0.65 \mu \mathrm{m}$ ). The addition did not affect the size of the YSZ grains in the 70A30Z composite. Compared to $\mathrm{CB}, \mathrm{CNTs}$ are more effective in inhibiting grain growth of YSZ.

CNT reinforced $\mathrm{Al}_{2} \mathrm{O}_{3}-\mathrm{YSZ}$ composites were characterized using Raman spectroscopy to discern whether the nanotube structure was retained after the SPS process. Figure 4 shows Raman spectra obtained from pristine multiwall carbon nanotubes, 80A20Z-2CNT and 70A30Z-2CNT composites in the 1000$3000 \mathrm{~cm}^{-1}$ range. Raman spectra of the samples are not provided in the low-frequency $\left(75-300 \mathrm{~cm}^{-1}\right)$ region. This is because the radial breathing mode (RBM) band in this range is related to the presence of tubes with fewer walls such as single-wall or doublewall carbon nanotubes. ${ }^{33)}$ The MWCNTs used in this study have diameters that are too large for RBM bands.

Raman absorption signals that are typical for multi-wall carbon nanotubes are observed at $1589 \mathrm{~cm}^{-1}$. These are assigned to the in-plane vibration of the $\mathrm{C}-\mathrm{C}$ bond ( $\mathrm{G}$ band). A peak at 1338 $\mathrm{cm}^{-1}$ is activated by the presence of disorder in carbon systems (D band), and the peak at $2665 \mathrm{~cm}^{-1}$ attributed to an overtone of the $D$ band $\left(G^{\prime}\right.$ band). The $G$ band is a tangential shear mode of $\mathrm{C}$ atoms that corresponds to the stretching mode in the graphite plane. The D band is a signature of defects and is known as the disordered or defect mode. It provides a measure of the structural disorder produced by amorphous carbon and any other defects.
For multi-wall carbon nanotubes, the D band is activated by the presence of vacancies, grain boundaries or other types of defects. ${ }^{15), 34), 35)}$ The CNTs in this study may have structural defects or most likely they are damaged by the nature of the SPS process. The positions and intensities of the bands are influenced by the temperatures and pressures that are applied during the SPS process. They are also influenced by residual thermal stresses that result from contraction of the matrix during the cooling stage. ${ }^{36)}$ The measured results suggest that although the CNTs contained defects, the CNT structure is preserved in the alumina based composites for these SPS sintering temperatures. This is indicated by the fact that the ratio of the $\mathrm{D}$ and $\mathrm{G}$ band intensities $\left(\mathrm{I}_{\mathrm{D}} / \mathrm{I}_{\mathrm{G}}\right)$ is $<2$ for all of the samples.

\subsection{Mechanical properties}

The Vickers microhardness, indentation fracture toughness and flexure strength of the composites are presented in Table 1. The addition of $10 \mathrm{vol} \%$ YSZ resulted in a higher Vickers hardness value of $\sim 20.5 \mathrm{GPa}$ than that of the monolithic $\mathrm{Al}_{2} \mathrm{O}_{3} \sim 19.4 \mathrm{GPa}$. The higher hardness of the $90 \mathrm{~A} 10 \mathrm{Z}$ composite compared to that of monolithic $\mathrm{Al}_{2} \mathrm{O}_{3}$ could be related to the formation of smaller grains as a result of the pinning effect of YSZ. A significant change in hardness values was not observed when the YSZ content increased from 10 to $20 \mathrm{vol} \%$. However, the addition of $30 \mathrm{vol} \%$ YSZ resulted in a lower Vickers hardness value of $\sim 18.6$ $\mathrm{GPa}$ due to the presence of a high volume fraction of the softer YSZ reinforcement phase with a hardness value of $\sim 12 \mathrm{GPa} .{ }^{17}$

On the other hand, the Vickers hardness showed a systematic decrease with increasing CNTs content for the $\mathrm{Al}_{2} \mathrm{O}_{3}-\mathrm{YSZ}-\mathrm{CNT}$ composites. The hardness of the $90 \mathrm{~A} 10 \mathrm{Z}$ composite decreased from $\sim 20.5$ to $\sim 18.5$ and $\sim 17 \mathrm{GPa}$ with the additions of 1 and $2 \mathrm{wt} \% \mathrm{CNTs}$, respectively. A slight reduction by $6.5 \%$ for $1 \mathrm{wt} \%$ and by $12 \%$ for $2 \mathrm{wt} \% \mathrm{CNT}$ addition was observed for the $80 \mathrm{~A} 20 \mathrm{Z}$ composites. The hardness values of the $70 \mathrm{~A} 30 \mathrm{Z}$ composites did not change significantly with the addition of CNTs. 4, 6 and 9\% reductions in the Vickers hardness were detected for $0.5,1$ and $2 \mathrm{wt} \% \mathrm{CNT}$ additions, respectively. The lowest Vickers hardness value, $\sim 16 \mathrm{GPa}$, was obtained for $70 \mathrm{~A} 30 \mathrm{Z}$ composites containing $2 \mathrm{wt} \% \mathrm{CB}$.

The indentation technique was used for fracture toughness measurements in this study. It is well known that the indentation method cannot be used as an accurate measurement technique for fracture toughness. However, it is widely used for comparing composites with relative densities of $\sim 98 \%{ }^{27)}$ The fracture toughness values are listed in Table 1 as a function of composition. The fracture toughness of monolithic $\mathrm{Al}_{2} \mathrm{O}_{3}$ increased from $\sim 2.8$ to $\sim 4.8 \mathrm{MPa} \cdot \mathrm{m}^{1 / 2}$ with the addition of $10 \mathrm{vol} \% \mathrm{YSZ}$. For the $80 \mathrm{~A} 20 \mathrm{Z}$ and $70 \mathrm{~A} 30 \mathrm{Z}$ binary composites, there is a significant increase in fracture toughness as the YSZ content increases from 10 to $20 \mathrm{vol} \%$ and then to $30 \mathrm{vol} \%$. The fracture toughness increases by 81.5 and $91.5 \%$ with 20 and 30 vol \% YSZ addition compared with monolithic $\mathrm{Al}_{2} \mathrm{O}_{3}$, respectively. The fracture toughness values of $\mathrm{Al}_{2} \mathrm{O}_{3}-\mathrm{YSZ}-\mathrm{CNT}$ triple composites showed a different trend depending on the CNT content. The addition of $0.5 \mathrm{wt} \%$ CNTs resulted in a slight increase in the fracture toughness of all three binary composites. Increments of 2.5, 2.7 and $1 \%$ in the fracture toughness values were achieved with the addition of $0.5 \mathrm{wt} \% \mathrm{CNTs}$ for $90 \mathrm{~A} 10 \mathrm{Z}, 80 \mathrm{~A} 20 \mathrm{Z}$ and $70 \mathrm{~A} 30 \mathrm{Z}$ composites, respectively. However, a reduction was observed in the fracture toughness values, as in Vickers hardness, for $\mathrm{Al}_{2} \mathrm{O}_{3}-$ YSZ-CNT composites with increasing CNT contents from 0.5 to 1 and $2 \mathrm{wt} \%$. Binary composites exhibited a minimal reduction in fracture toughness, $\sim 1.5 \%$ for $90 \mathrm{~A} 10 \mathrm{Z}$ and $\sim 4 \%$ for $80 \mathrm{~A} 20 \mathrm{Z}$ 
and 70A30Z, after $1 \mathrm{wt} \% \mathrm{CNT}$ addition. The decrement was small compared to when 2 wt $\%$ CNTs were added. The $90 \mathrm{~A} 10 \mathrm{Z}$ and 80A20Z composites with $2 \mathrm{wt} \% \mathrm{CNT}$ addition, possessed fracture toughness values of 4.3 and $4.5 \mathrm{MPa} \cdot \mathrm{m}^{1 / 2}$, respectively. These values are $\sim 11 \%$ lower than those of composites without CNT addition. Similarly, a $14.5 \%$ reduction was observed in the fracture toughness of the $70 \mathrm{~A} 30 \mathrm{Z}$ composite containing $2 \mathrm{wt} \%$ CNTs. When the effects of carbon based additives are compared, it is clear that $\mathrm{CB}$ addition results in slightly higher fracture toughness $\left(\sim 4.8 \mathrm{MPa} \cdot \mathrm{m}^{1 / 2}\right)$ than that of composites that contain CNTs $\left(\sim 4.6 \mathrm{MPa} \cdot \mathrm{m}^{1 / 2}\right)$. It is worth noting that large grains, weak bonding interfaces between CNTs and matrix grains, and intergranular fracture modes influence the low fracture toughness and the low strength of $\mathrm{Al}_{2} \mathrm{O}_{3}$ based materials. ${ }^{32)}$ The fracture mode in $70 \mathrm{~A} 30 \mathrm{Z}$ with $2 \mathrm{wt} \% \mathrm{CB}$ is a mixture of inter-granular and transgranular [Fig. 3(f)]. This could led to a stronger bonding than that of CNTs and higher fracture toughness, $\sim 4.85 \mathrm{MPa} \cdot \mathrm{m}^{1 / 2}$. A study ${ }^{15)}$ on pressureless sintered ZTA showed that while Vickers hardness remains approximately constant $(\sim 16$ to $15.6 \mathrm{GPa})$, fracture toughness of ZTA increased from 3.3 to $4.7 \mathrm{MPa} \cdot \mathrm{m}^{1 / 2}$ with $0.01 \mathrm{wt} \%$ CNTs addition because of the strong bonding between CNTs and matrix grains. In the same study, addition of $0.01 \mathrm{wt} \%$ MWCNT decreased the fracture toughness of pure $\mathrm{Al}_{2} \mathrm{O}_{3}$ from 3.3 to $3.0 \mathrm{MPa} \cdot \mathrm{m}^{1 / 2}$.

Table 1 shows that the addition of YSZ and CNTs also affected the flexure strength. The average measured flexure strength of monolithic $\mathrm{Al}_{2} \mathrm{O}_{3}(\sim 300 \mathrm{MPa})$ and $\mathrm{Al}_{2} \mathrm{O}_{3}-\mathrm{YSZ}$ binary composites increased with increasing YSZ content. This is due to the higher theoretical flexure strength of YSZ $\sim 1000 \mathrm{MPa} .{ }^{17)}$ The strength of $70 \mathrm{~A} 30 \mathrm{Z}$ composites sintered at $1400^{\circ} \mathrm{C}$ reached values that were as high as $\sim 590 \mathrm{MPa}$. In contrast, the strength of the $\mathrm{Al}_{2} \mathrm{O}_{3}-\mathrm{YSZ}-\mathrm{CNT}$ composites decreased significantly with the addition of $2 \mathrm{wt} \%$ CNTs. The addition of $0.5 \mathrm{wt} \%$ CNTs resulted in a $\sim 13 \%$ increase in the flexure strength of $90 \mathrm{~A} 10 \mathrm{Z}$ binary composites. Only a negligible increase $(\sim 2.9)$ was observed in the flexure strength with the addition of $0.5 \mathrm{wt} \% \mathrm{CNTs}$ for $80 \mathrm{~A} 20 \mathrm{Z}$. The strength did not change for the $70 \mathrm{~A} 30 \mathrm{Z}$ composite. However, a significant reduction was detected in the strength values, such in Vickers hardness and fracture toughness, for $\mathrm{Al}_{2} \mathrm{O}_{3}$-YSZ-CNT composites with increasing CNT content from 0.5 to 1 and $2 \mathrm{wt} \%$. The flexure strength decreased from 558 to $469 \mathrm{MPa}$, and 589 to $490 \mathrm{MPa}$ for $80 \mathrm{~A} 20 \mathrm{Z}$ and $70 \mathrm{~A} 30 \mathrm{Z}$ binary composites, respectively after $1 \mathrm{wt} \% \mathrm{CNT}$ addition. As expected, the reduction in the flexure strength is most noticeable with the addition of $2 \mathrm{wt} \%$ CNTs. The measured flexure strength remained approximately constant $(\sim 360 \mathrm{MPa})$ for all of the composites with 2 wt \% CNTs. These demonstrated composition independent behavior. This is most likely due to insufficient load bearing capacity of the grain boundaries for high CNT contents.

The mechanical properties of CNT reinforced ceramic matrix composites have been investigated in different studies. However, the exact effect of CNTs on mechanical properties is unclear. It is known that homogeneous distribution and absence of agglomeration of CNTs are essential for enhanced mechanical properties. In addition, improved mechanical properties are associated with a dense microstructure, fine grain size and good bonding between CNTs and the ceramic matrix. The mechanical properties are degraded when the structure contained higher amount of CNTs. In this study, the highest fracture toughness and flexure strength values were obtained with the addition of $0.5 \mathrm{wt} \% \mathrm{CNTs}$ for ternary composites. The position of CNTs in the inter-granular regions of the matrix grains cause fracture to occur along the grain boundaries and result in poor strengthening and toughening
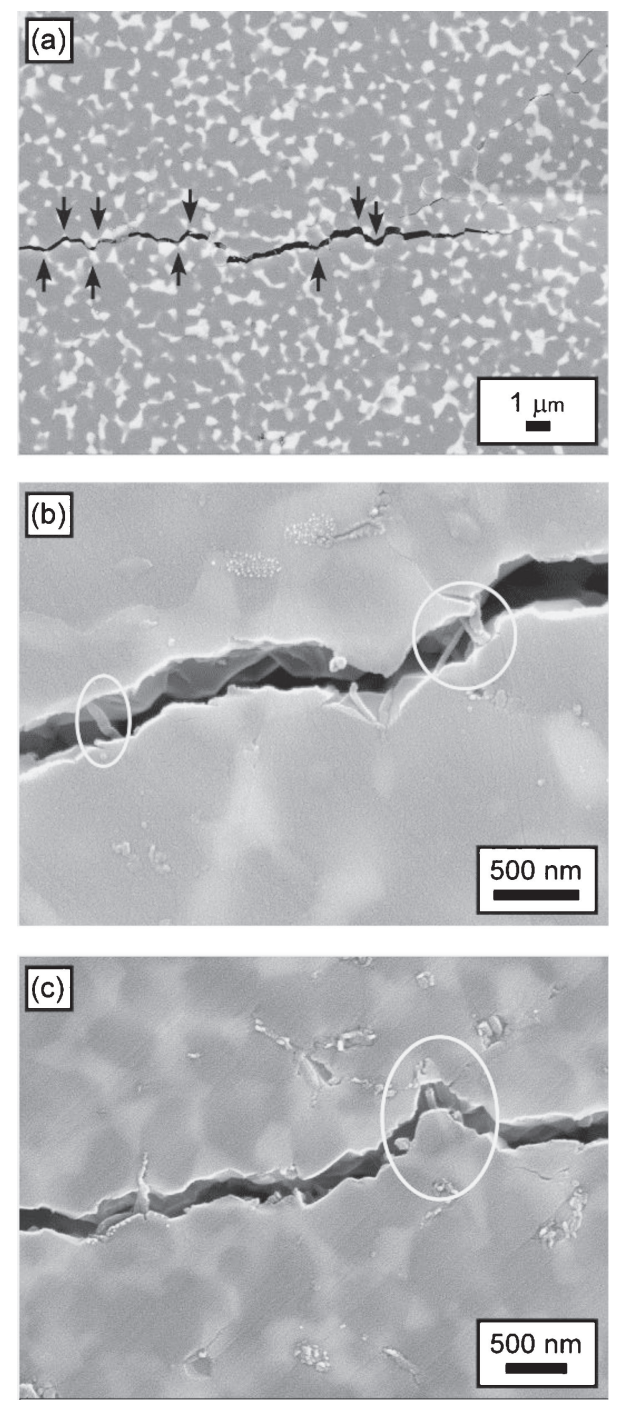

Fig. 5. SEM images of the crack propagations of the polished surfaces of 80A20Z-1CNT (a), 80A20Z-1CNT at high magnification (b), and 70A30Z-2CNT (c) ceramics.

contributions at 1 and $2 \mathrm{wt} \%$ additions. In other words, the possibility of formation of poor bonding between CNTs and matrix grains increase with the increasing CNTs content. Thus, the results indicate that the mechanical properties can be enhanced by the addition of an optimum amount of CNTs. Bocanegra-Bernal et al. ${ }^{37)}$ reported that the addition of $0.01 \mathrm{wt} \%$ of CNTs was optimal for achieving high Vickers hardness $(\sim 17 \mathrm{GPa})$ and fracture toughness $\left(\sim 4.4 \mathrm{MPa} \cdot \mathrm{m}^{1 / 2}\right)$ for ZTA ceramics. Another reason for the low strengthening of the CNTs could be the SPS process. The application of high pressure during the SPS process can damage the original CNT structure and cause the CNTs to form kinks, caps or spherical carbon onions. In addition, a large transverse current density during the SPS process might cause imperfections such as vacancies, interstitials, and local welds. ${ }^{38), 39)}$ Detailed microscopic examination is imperative for the investigation of the above mentioned defects. However, Raman results did indicate the presence of defective CNTs in this study.

Crack deflection and crack bridging effects of CNTs were observed on the polished surfaces of composites. Figure 5 shows the bridging effect of CNTs (indicated by black arrows) for an 80A20Z composite with $1 \mathrm{wt} \%$ CNTs. A few MWCNTs, having 

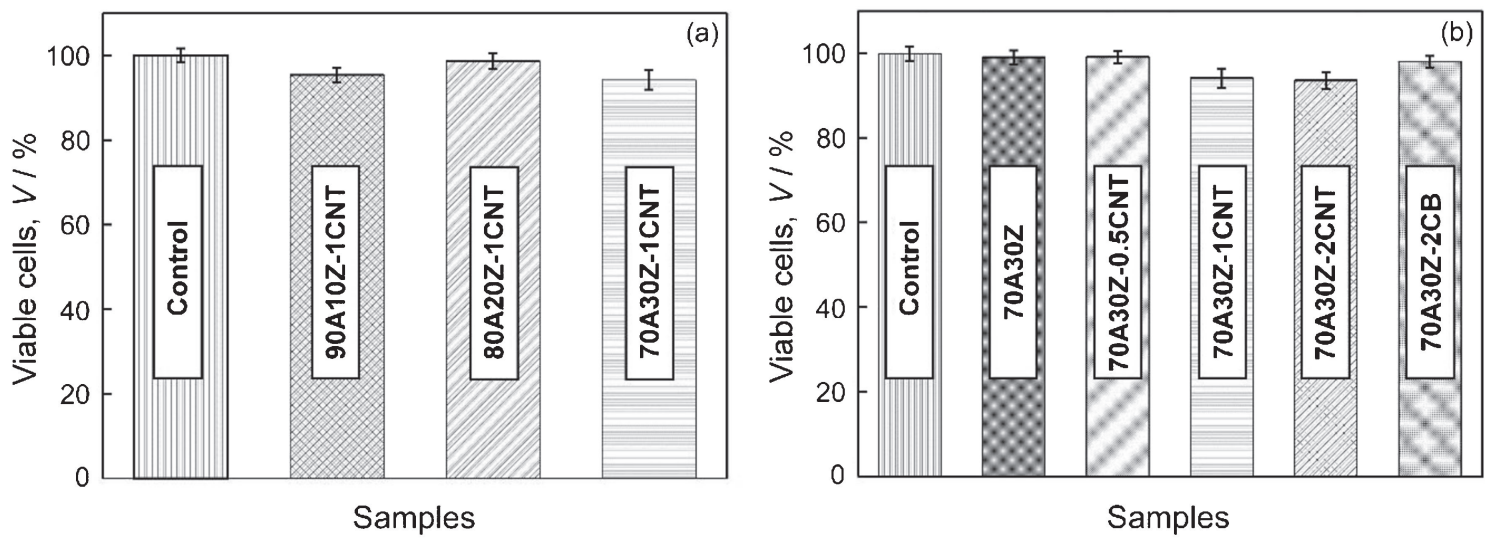

Fig. 6. Cell viability of human osteoblast cells after being cultured for a period of $24 \mathrm{~h}$ with the $\mathrm{Al}_{2} \mathrm{O}_{3}-\mathrm{YSZ}_{\mathrm{SZ}}$ composites having $1 \mathrm{wt} \%$ CNTs (a) and effect of CNTs and CB addition on cell viability of 70A30Z ceramics (b).

an average diameter of $\sim 50 \mathrm{~nm}$, are aligned perpendicular to the crack propagation direction (indicated by white circles) and bridge the crack. This phenomenon is similar to that observed in $\mathrm{Al}_{2} \mathrm{O}_{3}-\mathrm{MWCNT}$ and in $\mathrm{Al}_{2} \mathrm{O}_{3}-\mathrm{YSZ}-\mathrm{MWCNTs}$ composites. $^{40), 41)}$ Improved mechanical properties are likely when the number of bridging MWCNTs is larger. The bridging of CNTs at sites of the grain interface bridging has also been reported by Kim et al. ${ }^{42)}$ It is believed that crack bridging can delay crack propagation and can reduce the tensile stresses around crack tips. ${ }^{43), 44)}$

On the other hand, CNT pull-out was hardly ever detected in this study on the fracture surface of the composites. As is known, CNT pull-out can imply good bonding between CNTs and the matrix. The pulling-out of CNTs can disperse fracture energy. ${ }^{43}$ ) Bocanegra-Bernal et al. ${ }^{27)}$ achieved superior fracture toughness values $\left(\sim 8 \mathrm{MPa} \cdot \mathrm{m}^{1 / 2}\right)$ with an efficient pull-out and bridging effect of MWCNTs with $0.1 \mathrm{wt} \%$ in ZTA ceramics. The micrographs and mechanical property data obtained in the present study suggest that improvement in the mechanical properties is strongly dependent on the amount and positioning of CNTs, as well as the strength of cohesion between the matrix and the CNTs. This is in agreement with previous studies. ${ }^{15), 26), 43), 44)}$ The high hardness of $\mathrm{Al}_{2} \mathrm{O}_{3}\left(\sim 23.5 \mathrm{GPa}^{17)}\right)$ makes alumina-based ceramics useful for applications such as orthopedic and/or dental implants, where good abrasion and wear resistance are required. In addition, YSZ and CNT reinforcements result in a good combination of hardness, fracture toughness and flexure strength. Hence, the incorporation of YSZ and MWCNTs into $\mathrm{Al}_{2} \mathrm{O}_{3}$ can provide an optimum combination of hardness, fracture toughness, and flexure strength. Ceramics with 20 and 30 vol \% YSZ with 0.5 and $1 \mathrm{wt} \%$ CNTs are comparable with commercial dental or orthopedic implants and with implant equipment.

\subsection{Osteoblast cell viability}

Osteoblasts are bone-forming cells, and they proliferate on the surfaces of bones. Osteoblast differentiation is an important step for bone formation and remodeling. ${ }^{45)}$ To understand the effect of ceramic composition on cell viability, human osteoblast cells were placed in direct contact with the samples for $24 \mathrm{~h}$. The longterm effects, alkaline phosphatase activities and cell morphologies will be reported in another study. In the present work, Fig. 6 shows the cell viability of the samples depending on the YSZ and CNTs contents. The percentages of viable cells were in the range of 94 to $99 \%$. Consequently, preliminary cell viability studies indicate that composites with and without CNTs and/or CB showed no cytotoxicity to human osteoblast cells after $24 \mathrm{~h}$ of incubation.

\section{Conclusions}

Zirconia toughened alumina composites containing 10, 20 and $30 \mathrm{vol} \%$ of yttria stabilized zirconia and $0.5,1$, and $2 \mathrm{wt} \%$ CNTs were prepared by spark plasma sintering. The sintering was performed at $1400^{\circ} \mathrm{C}$ under $40 \mathrm{MPa}$ for $5 \mathrm{~min}$, resulting in composites with relative densities of $\sim 98 \%$.

The results of this study showed that the mechanical properties and the densification behavior of the zirconia toughened alumina composites reinforced with multi-wall carbon nanotubes are strongly dependent upon the amount and position of nanotubes in the microstructure. In addition, the strength of the cohesion between the matrix grains and the nanotubes had a remarkable effect on the properties of the alumina-based composites.

Further investigations, such as particular cytotoxicity, animal studies or in vivo tests are required. However, experimental results indicate that the composites containing 20 and $30 \mathrm{vol} \%$ YSZ with 0.5 and $1 \mathrm{wt} \%$ CNTs have mechanical properties that are comparable with those of currently used implant systems.

Acknowledgments This work was supported by the Scientific Research Project Funds of Istanbul Technical University with a project number of 36126. I am greatly indebted to Prof. Dr. G. Goller for providing production and characterization facilities. I am also thankful to Prof. Dr. M. Urgen for providing the facility for Raman measurements, and Prof. Dr. E. T. Oner for cell viability tests.

\section{References}

1) N. Dunne and R. W. Ormsby, "MWCNT Used in Orthopaedic Bone Cements" Ed. by M. Naraghi, InTech Open Access Publisher (2011) pp. 337-342.

2) J. P. Salvetat, J. M. Bonard and N. H. Thomson, Appl. Phys., A Mater. Sci. Process., 63, 255-260 (1999).

3) D. Lahiri, V. Singh, A. K. Keshri, S. Seal and A. Agarwal, Carbon, 48, 3103-3120 (2010).

4) J. Cho, A. R. Boccaccini and M. S. P. Shaffer, J. Mater. Sci., 44, 1934-1951 (2009).

5) S. R. Bakshi, D. Lahiri and A. Agarwal, Int. Mater. Rev., 55, 41-64 (2010).

6) S. Yamanaka, R. Gonda, A. Kawasaki, H. Sakamoto, Y. Mekuchi, M. Kuno and T. Tsukada, Mater. Trans., 48, 2506$2512(2007)$

7) I. Ahmad, H. Cao, H. Chen, H. Zhao, A. Kennedy and Y. Q. Zhu, J. Eur. Ceram. Soc., 30, 865-873 (2010). 
8) T. Wei, Z. Fan, G. Luo and F. Wei, Mater. Lett., 62, 641-644 (2008).

9) G. B. Yadhukulakrishnan, A. Rahman, S. Karumuri, M. M. Stackpoole, A. K. Kalkan, R. P. Singh and S. P. Harimkar, Mater. Sci. Eng., A, 552, 125-133 (2012).

10) S. R. Bakshi, V. Musaramthota, D. A. Virzi, A. K. Keshri, D. Lahiri, V. Singh, S. Seal and A. Agarwal, Mater. Sci. Eng., A, 528, 2538-2547 (2011).

11) A. B. Dalton, S. Collins, E. Muňoz, J. M. Razal, V. H. Ebron, J. P. Ferraris, J. N. Coleman, B. G. Kim and R. H. Baughman, Nature, 423, 703 (2003).

12) S. K. Smart, A. I. Cassady, G. Q. Lu and D. J. Martin, Carbon, 44, 1034-1047 (2006).

13) H. He, L. A. Pham-Huy, P. Dramou, D. Xiao, P. Zuo and C. Pham-Huy, Biomed Res. Int., 2013, 1-12 (2013).

14) L. P. Zanello, B. Zhao, J. Hu and R. C. Haddon, Nano Lett., 6, 562-567 (2006).

15) M. H. Bocanegra-Bernal, J. Echeberria, J. Ollo, A. GarciaReyes, C. Dominguez-Rios, A. Reyes-Rojas and A. AguilarElguezabal, Carbon, 49, 1599-1607 (2011).

16) I. Akin, E. Yilmaz, F. Sahin, O. Yucel and G. Goller, Ceram. Int., 37, 3273-3280 (2011).

17) L. L. Hench and J. Wilson, "An Introduction to Bioceramics", Advances Series in Ceramics, Volume 1, World Scientific Publishing Co. Pte. Ltd. (1993) p. 33.

18) A. H. De Aza, J. Chevalier, G. Fantozzi, M. Schehl and R. Torrecillas, Biomater, 23, 937-945 (2002).

19) J. Wang and R. Stevens, J. Mater. Sci., 24, 3421-3440 (1989).

20) M. E. Ebrahimi, J. Chevalier and G. Fantozzi, J. Mater. Res., 15, 142-147 (2000).

21) R. H. J. Hannink and M. V. Swain, Annu. Rev. Mater. Sci., 24, 359-408 (1994).

22) G. R. Anstis, P. Chantikul, B. R. Lawn and D. B. Marshall, J. Am. Ceram. Soc., 64, 533-538 (1981).

23) O. Ormanci, I. Akin, F. Sahin, O. Yucel, V. Simon, S. Cavalu and G. Goller, Mater. Sci. Eng., C, 40, 16-23 (2014).

24) F. Inam, H. Yan, T. Peijs and M. J. Reece, Compos. Sci. Technol., 70, 947-952 (2010).

25) J. Tatami, T. Katashima, K. Komeya, T. Meguro and T. Wakihara, J. Am. Ceram. Soc., 88, 2889-2893 (2005).

26) I. Ahmad, M. Unwin, H. Cao, H. Chen, H. Zhao, A. Kennedy and Y. Q. Zhu, Compos. Sci. Technol., 70, 1199-1206 (2010).

27) J. Echeberria, N. Rodriguez, J. Vleugels, K. Vanmeensel,
A. Reyes-Rojas, A. Garcia-Reyes, C. Dominguez-Rios, A. Aguilar-Elguezabal and M. H. Bocanegra-Bernal, Carbon, 50, 706-717 (2012).

28) J. W. An and D. S. Lim, J. Ceram. Process. Res., 3, 201-204 (2002).

29) D. J. Green, J. Am. Ceram. Soc., 65, 610-614 (1982).

30) B. Kibbel and A. H. Heuer, J. Am. Ceram. Soc., 69, 231-236 (1986).

31) A. L. Vasiliev, R. Poyato and N. P. Padture, Scr. Mater., 56, 461-463 (2007).

32) I. Ahmad, M. Islam, A. A. Almajid, B. Yazdani and Y. Zhu, Ceram. Int., 40, 9327-9335 (2014).

33) L. Alvarez, A. Righi, S. Rols, E. Anglaret and J. L. Sauvajol, Chem. Phys. Lett., 320, 441-447 (2000).

34) L. Bokobza and J. Zhang, Express Polym. Lett., 6, 601-608 (2012).

35) K. E. Thomson, D. Jiang, R. O. Ritchie and A. K. Mukherjee, Appl. Phys., A Mater. Sci. Process., 89, 651-654 (2007).

36) G. B. Yadhukulakrishnan, S. Karumuri, A. Rahman, R. P. Singh, A. K. Kalkan and S. P. Harimkar, Ceram. Int., 39, 6637-6646 (2013).

37) J. Echeberria, J. Ollo, M. H. Bocanegra-Bernal, A. GarciaReyes, C. Domingues-Rios, A. Aguilar-Elguezabal and A. Reyes-Rojas, Int. J. Refract. Met. Hard Mater., 28, 399-406 (2010).

38) D. Lahiri, S. Ghosh and A. Agarwal, Mater. Sci. Eng., C, 32, 1727-1758 (2012).

39) K. Yang, J. He, Z. Su, J. B. Reppert, M. J. Skove, T. M. Tritt and A. M. Rao, Carbon, 48, 756-762 (2010).

40) G. Yamamoto, M. Omori, T. Hashida and H. Kimura, Nanotechnology, 19, 315708 (2008).

41) M. Michálek, J. Sedláĉek, M. Parchoviansky, M. Michálková and D. Galusek, Ceram. Int., 40, 1289-1295 (2014).

42) S. W. Kim, W. S. Chung, K. S. Sohn, C. Y. Son and S. Lee, Mater. Sci. Eng., A, 517, 293-299 (2009).

43) J. P. Zhou, Q. M. Gong, K. Y. Yuan, J. J. Wu and Y. F. Chen, Mater. Sci. Eng., A, 520, 153-157 (2009).

44) M. Mortazavi, G. H. Majzoobi, A. N. Golikand, A. Reihani, S. Z. Mortazavi and M. S. Gorji, Rare Metals, 31, 372-378 (2012).

45) L. P. Zanello, B. Zhao, H. Hu and R. C. Haddon, Nano Lett., 6, 562-567 (2006). 